\title{
Sea Level of the Last Glaciation Maximum Based on In-Place Sediments on the Shelf off Sendai, Northeast Japan ${ }^{1)}$
}

\author{
Yoshiki SAIto $^{2)}$, Eiji MATSUMoto ${ }^{3)}$ and Kaoru Kashima ${ }^{4)}$
}

The lowest sea level during the last glaciation maximum is estimated to be $95 \pm 3 \mathrm{~m}$ below the present level based on the sedimentological, diatom and ${ }^{14} \mathrm{C}$ dating analyses of the in-place sediments of the two cores taken from the shelf off Sendai, Northeast Japan.

\section{Introduction}

The lowest sea level during the last glaciation maximum around Japan is estimated to be 80 to $130 \mathrm{~m}$ below the present level by morphological analyses of the shelf (Оненіма, 1982; Sato and MogI, 1982). The ${ }^{14} \mathrm{C}$ data and in-place sediments indicating the lowest sea level, however, have not been reported around Japan.

The core samples taken from the shelf off Sendai, Northeast Japan, are dealt with in this paper. The data indicating the lowest sea level during last glaciation maximum were obtained as a result of the sedimentological and diatom analyses and ${ }^{14} \mathrm{C}$ dating of these samples.

\section{Regional Setting}

\section{Morphology and surface sediments}

The studied area off Sendai is situated on the Pacific shelf of Northeast Japan and it is the widest part of the shelf with a width of about $80 \mathrm{~km}$ (Fig. 1). The shelf break is apparent to the south at about $37^{\circ} 55^{\prime} \mathrm{N}$ and is not clear to the north. It is, however, traced through both areas at approximately $145 \mathrm{~m}$ of water depth.

The surface sediments on the shelf are divided into Younger Suites, Older Sand A and Older

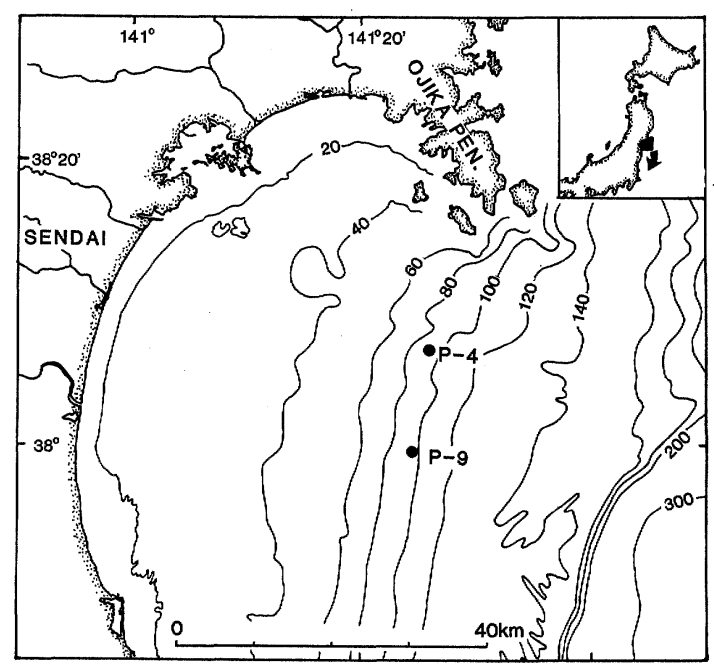

Fig. 1 Bathymetry of the shelf off Sendai and locations of the coring site

Depth contours in meters.

Sand B by HatToRI (1967). The first is modern sediments and the others are relict sediments deposited during the late Pleistocene to the early Holocene, and the early Holocene, respectively (HATtoRI, 1967; SAITo, 1989).

\section{Methods}

Field survey was conducted using $R / V$ TokaiNisei in 1986.

The collected cores were cut vertically, logged, slabbed $(25 \times 5 \times 1 \mathrm{~cm}), \mathrm{X}$-radiographed, and subjected to paleontological, chemical and textural

1) Recieved Sept. 2, 1988. Accepted Feb. 18, 1989.

2) Marine Geology Department, Geological Survey of Japan, Tsukuba 305.

3) Water Research Institute, Nagoya University, Nagoya 464-01.

4) Institute of Earth Science, College of General Education, Kyushu University, Fukuoka 810. 
analyses.

Carbon radiometric datings were performed at the Geological Survey of Japan with a benzene liquid scintillation method (Togashi and MaTsumoto, 1983) and by Teledyne Isotope (Code No.; I). All dates were calculated using the Libby half-life of 5,570 years, A. D. 1950 reference and one standard deviation.

One to two grams of the samples were taken from the cores and used for diatom analysis. Each sample was treated with hot $15 \%$ hydrogen peroxide to remove organic matters. Then it was treated with an undiluted hydrochloric acid to remove $\mathrm{CaCO}_{3}$ and washed with $\mathrm{H}_{2} \mathrm{O}$ by a centrifugal method. An appropriate amount was then mounted with Pleurax. Generally 150 to 200 frustules were counted in each sample (Kashima, 1985, 1986). Ten samples in the P-4 core and five samples in the P-9 core were analyzed with this procedure. According to Hustedt (1927 1930, 1931 1937, 1959, 1961 1964), Cleve-Euler (1951, 1952, 1953a, b, 1955), Hendey (1964), Patrick and Reimer (1966, 1975) and Goто (1979), diatoms which appeared in this study were identified.

\section{Results}

Sedimentary facies, molluscan species and ${ }^{14} \mathrm{C}$ dating

\section{1. $\mathbf{P}-4$ core}

This core sample was taken from the middle shelf off Sendai with a water depth of $94.5 \mathrm{~m}$. The core length is $248 \mathrm{~cm}$ (Fig. 2).

These sediments of this core are divided into three parts. The upper part consists of silt with a few sand layers and is found at 0 to about $85 \mathrm{~cm}$. This silt is deposited at the current rip zone between the coastal water mass and the Oyashio Current behind Ojika Peninsula (HosHino, 1958).

A vitric tephra layer is found at the lowest part, 80 to $85 \mathrm{~cm}$, and is zero to a few millimeters thick and white in color. This consists of pumice-type glass shards associated with bubblewalled flakes. The refractive index of glass shards ranges from 1.506 to 1.508 . This tephra is probable to be correlated with the Chuseri Pumice erupted from the Towada caldera,

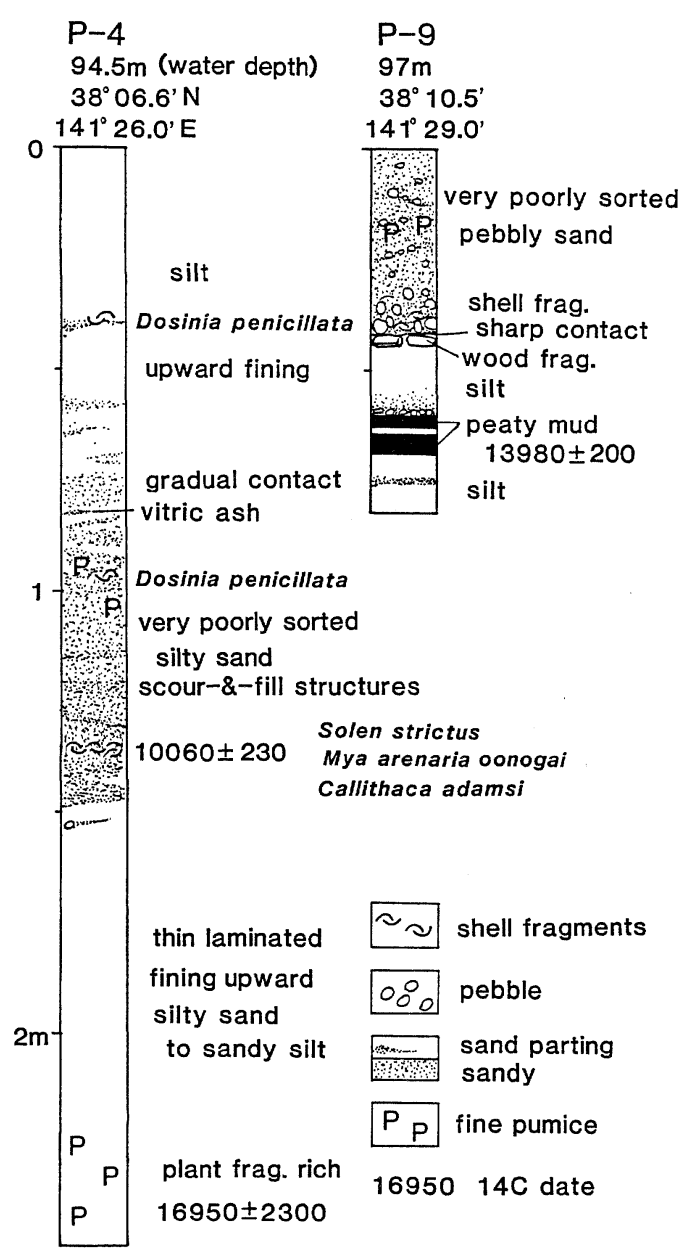

Fig. 2 Lithofacies of the P-4 and P-9 cores with ${ }^{14} \mathrm{C}$ dates and shell assemblage

northern Honshu, at about 5,500 y.B.P., based on these characteristics and those of Chuseri Pumice (Hayakawa, 1983).

The middle part is composed of very poorly sorted muddy medium sand and ranges from 85 to $150 \mathrm{~cm}$ in depth. Scour-and-fill structures are often found (Fig. 3). This part contains shells and shell fragments, they are particularly abundant in this lower part. The shells are Dosinia penicillata (REEVE) at the depths of 38 and $96 \mathrm{~cm}$ from the core top, and Solen strictus (GouLD), Mya arenaria oonogai MAKIYAMA and Callithaca adamsi (REEve) at the depths of 133 to $138 \mathrm{~cm}$. These molluskan assemblages indicate the mixed 


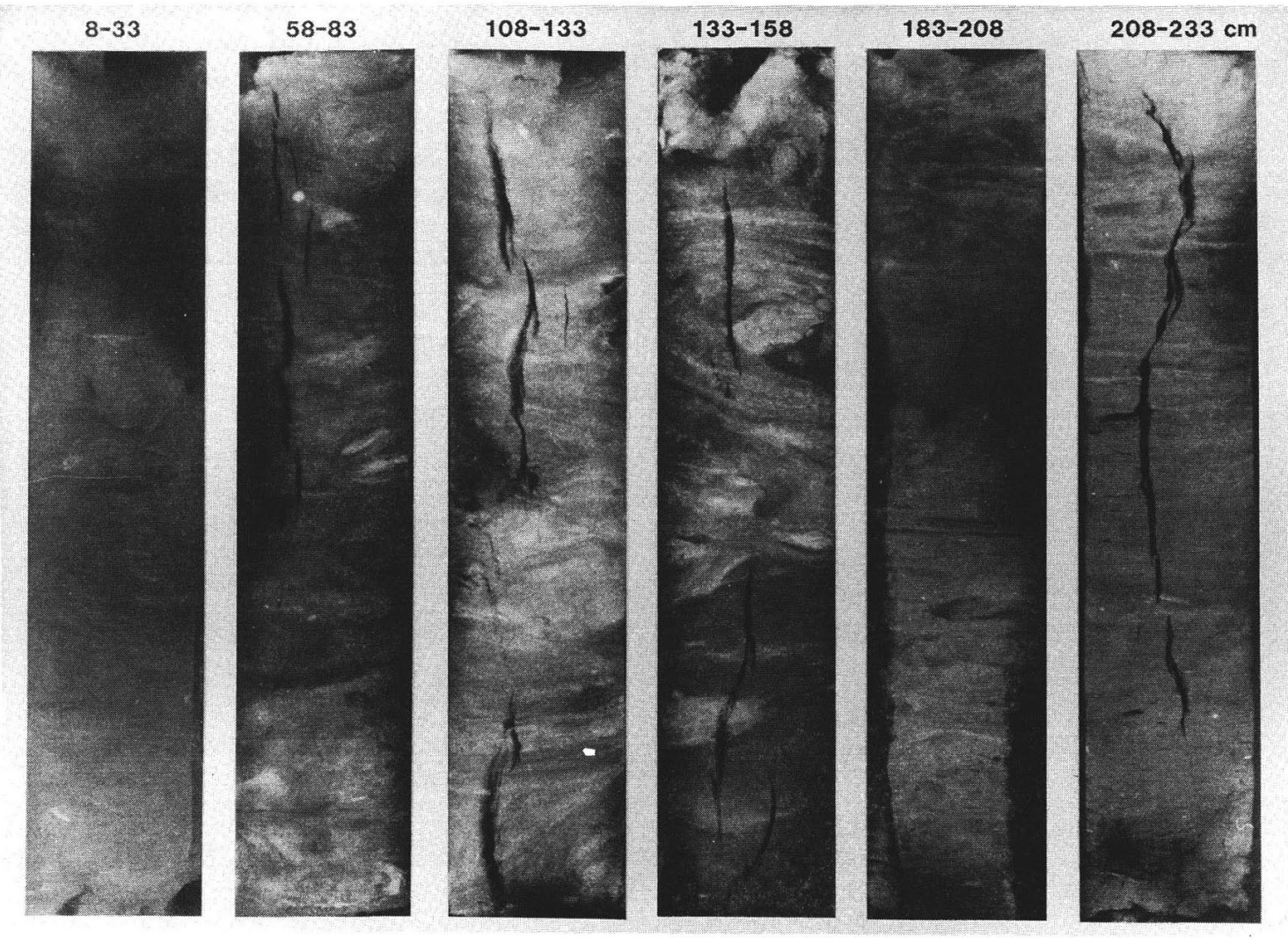

Fig. 3 Soft X-radiographs (negative) of the P-4 core

Table 1 List of ${ }^{14} \mathrm{C}$ dates

\begin{tabular}{|c|c|c|c|}
\hline Code No. & $\begin{array}{c}\text { Sample } \\
\text { Core:Depth }(\mathrm{cm})\end{array}$ & $\begin{array}{l}{ }^{14} \mathrm{C} \text { Date } \\
\text { y.B.P. }\end{array}$ & Materials \\
\hline JGS-344 & $\mathrm{P}-4: 133 \sim 138$ & $10,060 \pm 230$ & $\begin{array}{l}\text { Solen strictus, Mya arenaria } \\
\text { oonogai, Callithaca adamsi }\end{array}$ \\
\hline I-15126 & P-4:232 248 & $16,950 \pm 2,300$ & $\begin{array}{l}\text { Sandy mud } \\
\text { (plant frag. rich) }\end{array}$ \\
\hline JGS-331 & P-9:60 69 & $13,980 \pm 200$ & $\begin{array}{l}\text { Peaty mud } \\
\text { (carbon content: } 1.9 \% \text { ) }\end{array}$ \\
\hline
\end{tabular}

environments, that is, from intertidal zone to less than about $20 \mathrm{~m}$ in a water depth. The base of this shell layer is sharp. The ${ }^{14} \mathrm{C}$ date of these shells, taken from 133 to $138 \mathrm{~cm}$, is $10,060 \pm 230$ y.B.P. (JGS-344, Table 1).

The lower part is comprised of sandy silt to silty sand with plant fragments, and ranges from 150 to $248 \mathrm{~cm}$ is depth. A fining upward sequence is found. In the lowest part of this part, volcanic glass shards and fine pumices are abundant. Contents of plant fragments increase to downward. The ${ }^{14} \mathrm{C}$ date of this lowest part, organic materials in the sediments, is $16,950 \pm$ 2,300 y.B.P. (I-15126, Table 1).

2. P-9 core

This core was collected from the middle shelf 


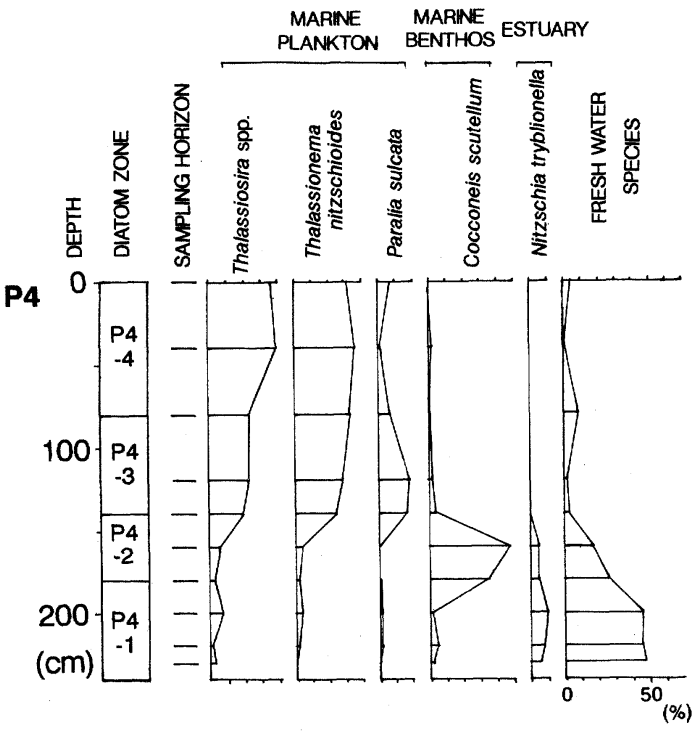

P9

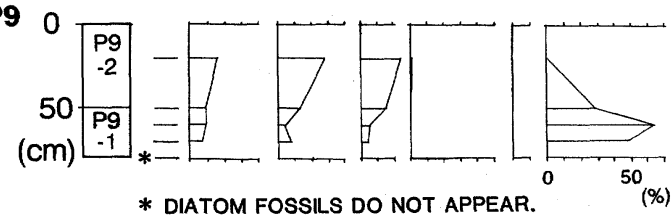

Fig. 4 Diatom diagrams of the P-4 and P-9 cores, showing the occurrence of the significant marine, estuary and fresh taxa

off Sendai with a water depth of $97 \mathrm{~m}$. It is $82 \mathrm{~cm}$ long (Fig. 2).

The core is divided into two parts. The upper part is made of very poorly sorted, muddy medium sand to sandy gravel with shell fragments. This part is $42 \mathrm{~cm}$ long. Scour-and-fill structures are well recognized. The lower part consists of alternating layers of sandy silt and peaty mud, and found at 42 to $82 \mathrm{~cm}$. The boundary of both parts is sharp. The ${ }^{14} \mathrm{C}$ date of the peaty mud, from 60 to $69 \mathrm{~cm}$, is $13,980 \pm 200$ y.B.P. (JGS-331, Table 1).

\section{Diatom assemblages}

The sediments of these cores can be divided into four zones in the P-4 core and two zones in the $\mathrm{P}-9$ core (Fig. 4 ).

\section{P-4 core}

Four diatom assemblage zones are recognized in this core, these are P-4-1, $-2,-3$ and -4 zones in ascending order.
P-4-1 (depth: 180 to $230 \mathrm{~cm}$ ) :

This zone is characterized by fresh water diatoms which constitute 40 to $50 \%$ of the total diatomaceous flora. They are Fragilaria construens (Ehrenderg) Grunow, $F$. pinnata EhrenberG, $F$. brevistriata GRUNOw, Synedira rumpens KüTZING, and Cocconeis placentula EHRENBERG. Marine and brackish water diatoms are commonly found, particularly Nitzschia tryblionella $\mathrm{HANTSCH}_{\mathrm{A}}$ living in river-mouth environment (HUSTEDT, 1937 1930; HENDEY, 1964), is abundant.

Sedimentary environment of this zone is inferred to be river-mouth or brackish water, including tidal river area, because fresh-water and marine diatoms are mixed and Nitzschia tryblionella is abundant in this zone.

P-4-2 (140 to $180 \mathrm{~cm})$ :

This zone is characterized by marine benthic diatoms. Cocconeis scutellum EHRENBERG constitutes $40 \%$ of the diatomaceous flora. Marine planktonic diatoms, fresh-brackish water diatoms and fresh-water diatoms are commonly recognized.

Sedimentary environment of this zone is inferred to be very shallow marine, less than about $10 \mathrm{~m}$ deep, and close to shoreline, because C. scutellum is growing on seaweeds (Kosugr, 1988) and sea bottom at depths of less than about 10 meters.

P-4-3 (80 to $140 \mathrm{~cm})$ :

This zone is mostly composed of marine planktonic diatoms. Paralia sulcata (EHRENBERG) CLEVE, Thalassionema nitzchioides HUSTEDT and Thalassionsira spp. constitute 20 to $30 \%$ of the diatomaceous flora, respectively.

Sedimentary environment of this zone is inferred to be inner bay, lower than open sea in salinity. Because Paralia sulcata is living in polyhaline brackish lagoons, about $15 \%$ in salinity, and inner bay areas (KASHIMA, 1987).

P-4-4 $(0$ to $80 \mathrm{~cm})$ :

This zone is mostly composed of marine planktonic diatoms. Thalassionema nitzchioides and Thalassionsira spp. constitute 30 to $40 \%$, respectively, and the content of $P$. sulcata is less than $10 \%$.

Sedimentary environment of this zone is inferred to be bay and open shelf strongly 
influenced by an open sea water mass. This is because the ratio of $P$. sulcata in this zone is lower than that of the P-4-3 zone, and modern diatom assemblages in this location are the same.

\section{P-9 core}

Two zones are recognized in this core and these are $\mathrm{P}-9-1$ and -2 zones in ascending order.

P-9-1 (50 to $70 \mathrm{~cm}$ ) :

Fresh water diatoms, Fragilaria construens, $F$. pinnata, Melosira granulate (EHRENBERG) RALFS etc., occupy 50 to $60 \%$ of this zone, with marine and brackish-fresh water diatoms. Sample below $80 \mathrm{~cm}$ do not yield diatoms.

Sedimentary environment of this zone is inferred to be tidal-river area, river-mouth, or ephemeral lagoon, e.g., located in inter-beach ridges. This is based on the fact that the fresh water diatoms occupy the majority, and that marine and brackish diatoms are mixed with them.

\section{P-9-2 (less than $50 \mathrm{~cm}$ ) :}

This zone is characterized by marine planktonic diatoms, contents of Paralia sulcata, Thalassionema nitzchioides and Thalassionsira spp. are 20 to $30 \%$, respectively.

Sedimentary environment of this zone is inferred to be inner bay area. This diatom assemblage resembles that of the P-4-3.

\section{Discussions and Conclusions}

\section{Depositional unit}

Core samples are divided into three units based on the lithofacies, shell and diatom assemblages, and ${ }^{14} \mathrm{C}$ dating results.

The first unit is modern sediments deposited under the present environment, found at 0 to $85 \mathrm{~cm}$ in the P-4 core. This unit is correlated with Younger Suites of HatToRI (1967) and is deposited at the current rip zone between the coastal water mass and the Oyashio Current behind Ojika Peninsula (Hoshino, 1958).

The second unit is recognized at 85 to 140 (or $180) \mathrm{cm}$ in the P-4 core and at 0 to $42 \mathrm{~cm}$ in the P-9 core. This unit is inferred to contain redeposited sediments, because fossil assemblages indicate wide range of sedimentary environment. Moreover, the shells from the lowest part of this unit are not in-situ and are transported from the original locations in-place to deeper area of this stations. This is inferred from the fact that the sea level estimated from these samples at about 10,060 y.B.P. is too deep in comparison with the sea level around Japan at the same age. Because the sea level estimated from the samples is the coring depths of $94.5 \mathrm{~m}$ and $97 \mathrm{~m}$ minus the depths of the sedimentary environment, intertidal to very shallow marine, that is, about 70 to $95 \mathrm{~m}$. Whereas the sea level around Japan is 30 to $50 \mathrm{~m}$ at about 10,000 y.B.P. (OTA et al., 1982). And scour-and-fill structures are commonly recognized in this unit. These facts indicate that this unit contain the sediments deposited under high shear stress, that is, it is possible to be deposited by bottom currents with offshore directions.

The third unit, found at 180 to $248 \mathrm{~cm}$ in the $\mathrm{P}-4$ core and at 42 to $82 \mathrm{~cm}$ in the P-9 core, was deposited ranging from 17,000 to 14,000 y.B.P., that is during the lowest sea level in the last glaciation maximum (DuPLESSY et al., 1981, 1986; BERGER et al., 1987). Diatom assemblages from this unit of two cores indicate river-mouth or ephemeral lagoon environment.

Changes in diatom assemblages in the $\mathrm{P}-4$ core show transition from river-mouth to very shallow marine environment and then to inner bay and to bay or shelf environment in ascending order. These changes indicate that the P-4 station has gradually deepened. Changes of depositional environment observed in the P-9 core are mostly the same as those in the P-4 core. These are, however, not smooth in its changes and the P-4-2 and P-4-4 horizons are lacking compared with the $\mathrm{P}-4$ core.

\section{Estimated sea level}

The relative sea level during the last glaciation maximum in this area is concluded to be about $95 \pm 3$ meters below the present level from sedimentological and diatom analyses. The bases are as follows (Table 2).

The estimated sea level from two cores ranges from 88 to $97 \mathrm{~m}$ below the present level, because the sample in the P-4 core was taken from water depth of $94.5 \mathrm{~m}$ and the position of the third unit is 1.8 to $2.48 \mathrm{~m}$ beneath the sea bottom ( $\mathrm{P}-4-1$ zone) and the sedimentary environment 
Table 2 Estimated lowest sea level

\begin{tabular}{l|c|c|c|c|c}
\hline & $\begin{array}{c}\text { Water } \\
\text { depth }\end{array}$ & $\begin{array}{c}\text { Subbottom } \\
\text { depth }\end{array}$ & $\begin{array}{c}\text { Sedimentary } \\
\text { environment }\end{array}$ & $\begin{array}{c}\text { Estimated } \\
\text { sea level }\end{array}$ & $\begin{array}{c}\text { Age } \\
\text { y.B.P. }\end{array}$ \\
\hline P-4 core & $\begin{array}{l}94.5 \mathrm{~m} \\
\text { P-9 core }\end{array}$ & $\begin{array}{l}1.80 \sim 2.48 \mathrm{~m} \\
\mathrm{~m}\end{array}$ & $\begin{array}{c}\text { 0 to ca. }-10 \mathrm{~m} \\
0.42 \sim 0.82 \mathrm{~m}\end{array}$ & $\begin{array}{c}97 \sim 86 \mathrm{~m} \\
\text { 0 to ca. }-10 \mathrm{~m}\end{array}$ & $\begin{array}{c}\text { ca. } 17 \mathrm{k} \\
\text { ca. } 14 \mathrm{k}\end{array}$ \\
\hline
\end{tabular}

inferred from diatom assemblages is intertidal zone to river-mouth which is shallower than about $10 \mathrm{~m}$ of water. On the other hand, the sample in the P-9 core was taken from water depth of $97 \mathrm{~m}$ and the second unit is located 0.42 to $0.82 \mathrm{~m}$ beneath the sea bottom. And the sedimentary environment inferred from diatom assemblages is intertidal zone to river-mouth which is shallower than about $10 \mathrm{~m}$ of water, or ephemeral lagoon located in inter-beach ridges, less than 5 to $6 \mathrm{~m}$ of water depth.

The minimum sea level of these estimations corresponds to the maximum depth of rivermouth environment. This maximum depth, however, is not applied. If the samples were deposited in a depression of $10 \mathrm{~m}$ deep in a rivermouth, this depression will be buried during the following transgression and thick deposits will be formed. But post-glaciation sediments in the $\mathrm{P}-4$ core are only about $2 \mathrm{~m}$ thick and changes of diatom assemblages is smooth. Moreover topographical depressions have not been recognized at the coring station. This means that the environment of the third unit in the $\mathrm{P}-4$ core is not deep and nearly intertidal or a few meters deep.

Moreover as the third unit does not contain characteristic sedimentary structure formed in an intertidal zone, such as flaser bedding formed by tidal currents in tidal flat, or swash cross stratification formed by waves at beachface, it is highly possible that the sedimentary environment is a few meters deep. The relative sea level in this area is concluded to be about $95 \mathrm{~m}$ below present sea level. This conclusion is supported by peaty sediments, estimated to be deposited in a flood plain, from $92 \mathrm{~m}$ of water depth off Sendai (Honza et al., 1982).

\section{Correlation}

Sediments on the shelf off the Pacific coast of Northeast Japan deposited during the last glaciation have been reported as follows. These are Older Sand A off Sendai (HATTORI, 1967) and ancient coastal sediments off Kuji River (KAGAMI and NASU, 1964). The former is correlated with the second unit, and it is strongly possible that the latter is correlated with the third unit.

\section{Acknowledgments}

I would like to thank Prof. H. MACHIDA of Tokyo Metropolitan University for analyses and identification of tephra, and the staff of Marine Geology Department of GSJ for support of this study and to the crew of $R / V$ Tokai-Nisei for assisting with operations on board. I am indebted to Dr. K. OHshima of GSJ for identification of shells and for his warm encouragements through the work. I am grateful to Dr. Y. SHIMAZAKI of Nikko Exploration and Development Co. for his critical improvement of the manuscript. This work was supported by the special research programs, Anthropogenic Influence of the Sedimentary Regime of an Open Type Bay, Geological Survey of Japan.

\section{References}

Berger, W. H., Killingley, J. S. and Vincent, E. (1987) Time scale of the Wisconsin/Holocene transition: oxygen isotope record in the western equatorial Pacific. Quaternary Research, 28, p. 295-306.

Cleve-Euler, A. (1951) Die Diatomeen von Schweden und Finnland. Kungl. Svenska Vetenskapsakademiens Handlingar, 4, Ser. 2, no. 1, 161 p.

Cleve-Euler, A. (1952) Die Diatomeen von Schweden und Finnland. ibid., 4, Ser. 3, no. 3, 153p.

Cleve-Euler, A. (1953a) Die Diatomeen von Schweden und Finnland. ibid., 4, Ser. 4, no. 1, 158p.

Cleve-Euler, A. (1953b) Die Diatomeen von Schweden und Finnland. ibid., 4, Ser. 4, no. 5, 255p.

Cleve-Euler, A. (1955) Die Diatomeen von Schweden und Finnland. ibid., 4, Ser. 5, no. 4, 232p.

Duplessy, J. C., Delibrias, G., Turon, J. L., Pujol, C. and Dupray, J. (1981) Deglacial warming of the north- 
eastern Atlantic Ocean: correlation with the paleoclimatic evolution of the European continent. Palaeogeogr. Palaeoclimatol. Palaeoecol., 35, p. 121-144.

Duplessy, J. C., Arnold, M., Maurice, P., Bard, E., Duprat, J. and Moyes, J. (1986) Direct dating of the oxygen-isotope record of the last deglaciation by ${ }^{14} \mathrm{C}$ accelerator mass spectrometry. Nature, 320, p. 350-352.

Goto, T. (1979) On the sessile diatoms in the brackish water area of the River Yodo, II. Jap. J. Limnol., 40, p. 191-200. (in Japanese with English Abstract)

Hattori, M. (1967) Recent Sediments of Sendai Bay, Miyagi Prefecture, Japan. Sci. Rep. Tohoku Univ., 2nd Ser. (Geol.), 39, p. 1-61.

HayaKawa, Y. (1983) Chuseri tephra formation from Towada Volcano, Japan. Bull. Volcanol. Soc. Japan, Ser. 2, 28, p. 263-273. (in Japanese with English Abstract)

Hendey, N. I. (1964) Bacillariophyceae (Diatom). An introductory account of the smaller algae of British coastal water, Part 5, Her Majesty Stationary Office, London, 317p.

Honza, E., Inoue, E., Arita, M. and Ishihara, T. (1982) Activities of marine geological survey around Japan. Chishitsu News, no. 331, p. 13-35. (in Japanese)

Hoshino, M. (1958) The shelf sediments in the adjacent seas of Japan. Mono. Assoc. Geol. Collaboration, 7, 40p. (in Japanese with English Abstract)

Hustedt, F. (1927 1930) Die Kieselalgen Deutschlands, Oesterreichs und der Schweiz unter Berücksichtigung der ubrigen Länder Europas sowie der angrenzenden Meeresgebiete. Dr. L. Rabenhorst's Kryptogamen-Flora von Deutschland, Oesterrichs und der Schweiz, VII, Leipzig, 920p.

Hustedt, F. (1931 1937) Die Kieselalgen Deutschlands, Oesterreichs und der Schweiz unter Berücksichtigung der übrigen Länder Europas sowie er angrenzenden Meeresgebiete. ibid., VII, Leipzig, $736 \mathrm{p}$.

Hustedt, F. (1959) Die Kieselalgen Deutschlands, Oesterreichs und der Schweiz unter Beruicksichtigung der übrigen Länder Europas sowie der angrenzenden Meeresgebiete. ibid., VII, Leipzig, p. 737-1179.

Hustedt, F. (1961 1964) Die Kieselalgen Deutschlands, Oesterreichs und der Schweiz unter Berücksichtigung der übrigen Länder Europas sowie der angrenzenden Meeresgebiete. ibid, VIII, Leipzig, $556 \mathrm{p}$.

Kagami, H. and NASU, N. (1964) The Paleo-Kuji River-A sample of buried valley on the shelf due to the sea level rise during the post glacial age. Studies on
Oceanography, Hidaka Jubilee Commitee, Tokyo, p. 538-549. (in Japanese with English Abstract)

KashimA, K. (1985) Holocene diatom assemblages in Takagami Lowland, central part of Choshi peninsula, and its relation to changes of sea-level. The Quaternary Research (Daiyonki-Kenkyo), 24, p. 125-138. (in Japanese with English Abstract)

Kashima, K. (1986) Holocene successions of diatom assemblages in alluvium and those relations to paleo-geographical changes. Geographical Review of Japan, 59 (Ser. A), p. 383-403.

Kashima, K. (1987) Ecology of living Diatom and the sedimentary processes of diatom valves at the brackish lakes in Kamikoshiki Island, Kyushu, Japan. Abstracts, 1987 Annual Meeting, Paleont. Soc. Japan, p. 84. (in Japanese)

Kosugi, M. (1988) Classification of living diatom assemblages as the indicator of environments, and its application to reconstruction of paleoenvironments. The Quaternary Research (Daiyonki-Kenkyo), 27, p. 1-20 (in Japanese with English Abstract)

Ota, Y., Matsushima, Y. and Moriwaki, H. (1982) Notes on the Holocene sea-level study in Japan —-On the basis of "Atlas of Holocene Sea-Level Records in Japan"-_. The Quaternary Research (DaiyonkiKenkyo), 21, p. 133-144. (in Japanese with English Abstract)

OHsHima, K. (1982) Lowest sea-level in the last glaciation of the Japanese Islands. The Quaternary Research (Daiyonki-Kenkyo) , 21, p. 211-222. (in Japanese with English Abstract)

Patrick, R. and Reimer, C. W. (1966) The diatoms of the United State. Monogr. Acad. Nat. Sci. Philadelphia, 1, 668p., Philadelphia.

Patrick, R. and Reimer, C. W. (1975) The diatoms of the United State. ibid., 13, 213p., Philadelphia.

SaITo, Y. (1989) Modern storm deposits in the inner shelf and their reccurence intervals, Sendai Bay, northeast Japan. In A. TAIRA, and F. MASUdA (eds.) Sedimentary Facies in the Active Plate Margins, TERRA Sci. Pub., p. 331-344.

Sato, T. and Mogi, A. (1982) Sea level change in the Japan Sea deduced from submarine terraces and buried shelf channels. The Quaternary Research (Daiyonki-Kenkyu), 21, p. 203-210. (in Japanese with English Abstract)

Togashi, S. and Matsumoto, E. (1983) Radiocarbon dating methods using benzene liquid scintillation. Bull. Geol. Surv. Japan, 34, p. 513-527. (in Japanese with English Abstract) 


\title{
仙台沖の陸棚域から採取した柱状試料から推定される最終永期極寒期の海水準
}

\author{
斎藤文紀・松本 英二・鹿島 薰
}

仙台沖の陸棚域から採取した P-4 と P-9 の 2 本の柱 状試料について, 堆積学的分析と珪藻分析, 含有する貝

片と有機物の ${ }^{14} \mathrm{C}$ 年代測定を行った結果, 両柱状試料
の下部は, 最終氷期極寒期の低海水準期の汀線近くの堆 積物であり，これから推定される海水準は， $-95 \pm 3 \mathrm{~m}$ である。

Plate I Typical diatoms

1. Thalassiosira sp.

2. Actinocyclus sp.

3 4. Paralia sulcata (EHRENBERG) KüTZING

5 6. Thalassionema nitzschioides Grunow

7 8. Cocconeis scutellum EHRENBERG

9. Diploneis smithii (BRĒBISSION) CLEVE

10. Rhaphoneis surirella (EHRENBERG) GRUNOW ex VAN HEURUCK

11. Nitzschia acuminata (W. SmITH) GRUNow

12 13. Nitzschia tryblionella $\mathrm{H}_{\mathrm{ANTZSCH}}$

14. Rhopalodia gibberula (EHRENBERG) O. MÜLleR

15. Synedra pulchella KüTzing

16. Navicula radiosa KützING

17. Eunotia veneris (KÜTZING) O. MüLLER

18. Cocconeis placentula EHRENBERG

19. Pinnularia viridis (NITZSCH) EHRENBERG

1 6. Marine (plankton)

7 11. Marine (benthos)

12 15. Estuary

16 19. Fresh water 
斎藤・松本・鹿島：図版 I
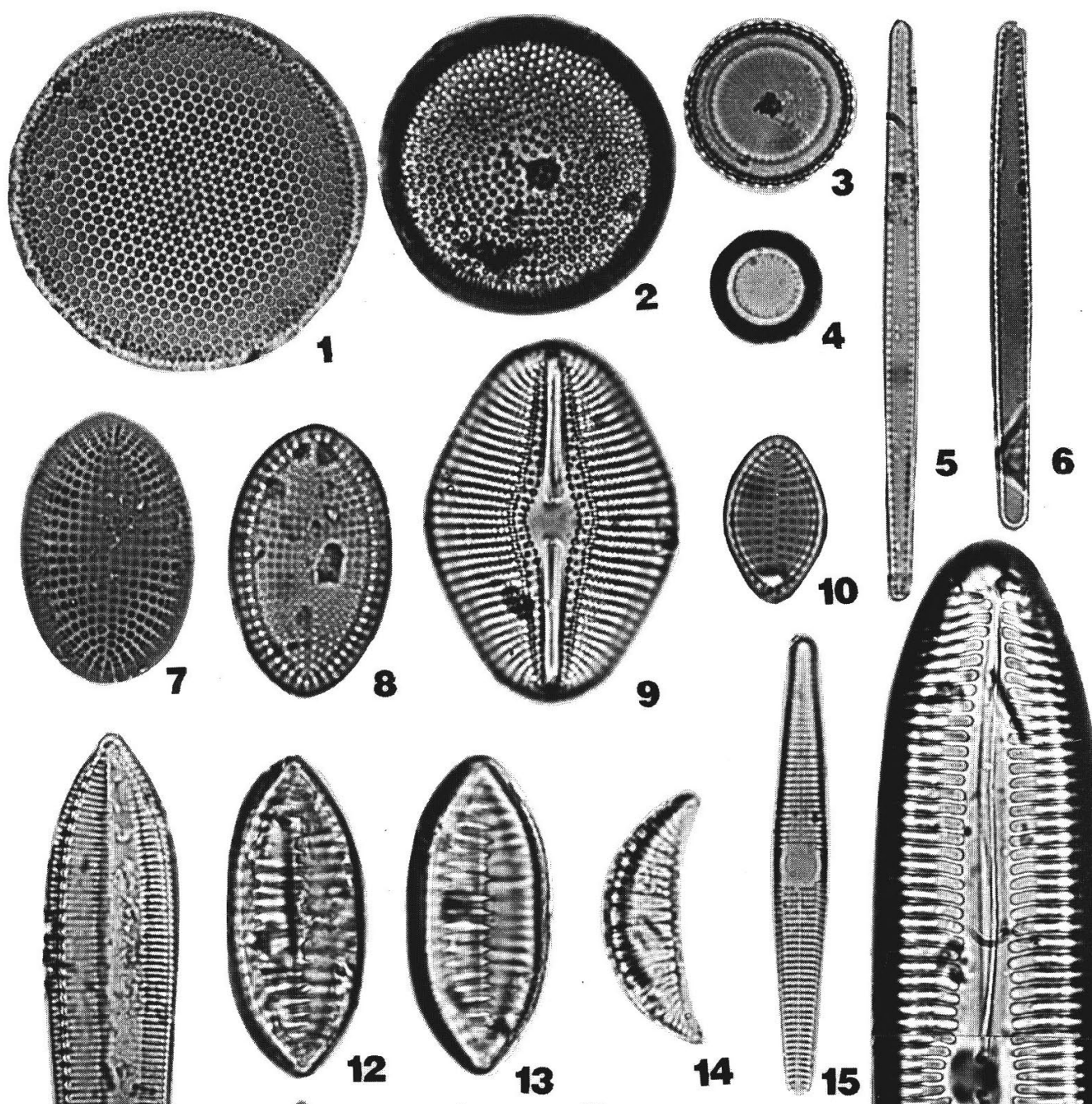

点
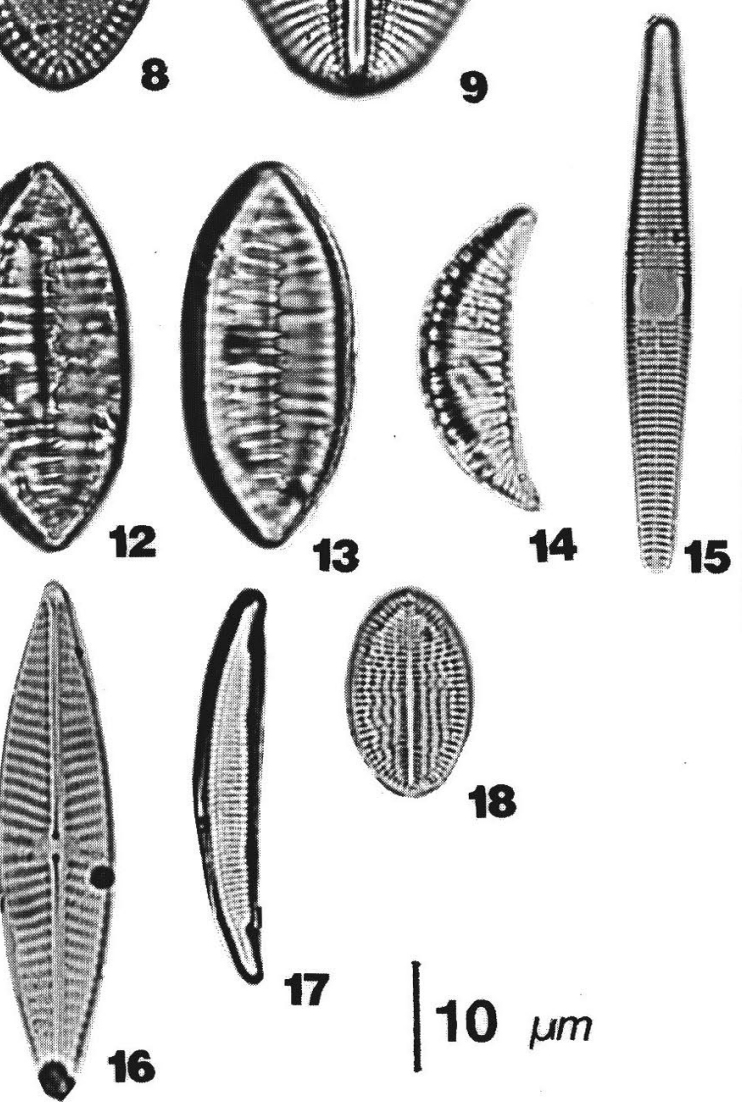

Ex 2 E

$\leq-11.2$

$\Rightarrow$ a

\pm 표

$\stackrel{2}{=}$

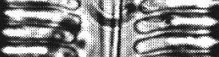

-3 =

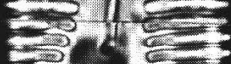

날

$=3 \sqrt{\mathrm{C}}$

25, $\mathrm{E}$

-3 es

9 당

도

-1 E

$\simeq 5$

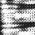

$\simeq$ es

$\therefore$. 2

$\because$ E

$=-5 \mathrm{~s}$

$\because 5$

11

16

필 